\title{
Effective Integration of Education of College Students' Socialist Core Values into Campus Culture Construction
}

\author{
Chao Wang ${ }^{1, a}$ and Junzheng Wang ${ }^{2, \text { b* }}$ \\ ${ }^{1}$ Xincheng Street 2888, Jilin Agricultural University, Changchun, Jilin Province 130118, PR China \\ a29251275@qq.com, 59545966 @ qq.com \\ "The corresponding author
}

Keywords: Effective; Socialist core values; Construction of campus culture; Measures

\begin{abstract}
The socialist core values are the major innovation theories put forward by the Party in ideological construction. As a successor of communism, undergraduates should learn and practice the core values of socialism. The effective integration of the socialist core values education into the construction of campus culture, from the material, spiritual, institutional, behavior and other aspects at the same time start. Thus, to promote the formation of college students' socialist core values.
\end{abstract}

\section{It Is Important to Integrate the Education of the Socialist Core Values of College Students into the Campus Construction Effectively}

Culture is a nation created, the sum of all material and spiritual wealth. It runs through the development process of the nation. Campus culture is a university in its own existence and development of the historical process of formation embodies the spirit of a university.

University campus culture can be invisible in the college students to cultivate the role of mind, related to each student's physical and mental health, related to each student's growth, talent and future development. As the "cradle of talent" university, the essence of campus culture is to educate and nurture people. Youth is the future of the country, the nation's hope. College students are the young talents, is the reserve army of the motherland. As the lyrics write, they are the successor of the great cause of our communism. They shoulder a great historical mission; they are well-off society, for the happiness of the people, and constantly struggle with. The Chinese nation's great renaissance of the Chinese dream, one day will come true.

Thus, it is very important to integrate the socialist core values education into the construction of campus culture and to strengthen the education of the socialist core values of college students. It is also an essential requirement to ensure the prosperity of the cause of socialism with Chinese characteristics.

\section{The Effective Way to Integrate the Socialist Core Values Education into the Campus Construction}

The Effective Integration of Socialist Core Values Education into the Campus Material Culture. Material culture was composed of two aspects. The first is material, the second is culture. The most important thing is culture. Campus culture, through the material culture. Material is the specific form of campus culture. The material plays an important role in turning the invisible into tangible and abstracting concrete. The Soviet Union famous educator Suhomlinski had the campus environment education function likened to "let every wall of the school will speak." Campus material culture refers to a school campus architecture and campus design.

The Effective Integration of Socialist Core Values Education into the Campus Spiritual and Cultural Construction. Campus spirit and culture is a university in its own existence and development of the historical process of formation, and for the whole school staff and students agree. Campus with the cultural elements of the material existence of carrying the school's history, school philosophy, the spirit of the University and the times style. It is the soul of the campus culture and the core, with a strong spiritual strength. Although it is invisible, but it spread all over 
the campus every place. It is in the culture, in the offerings, the college students played a role in cultivating. It achieves the spirit, spirit and character of university students.

The Effective Integration of Socialist Core Values Education into Campus Behavior and Cultural Construction. The socialist core values should not only be a concept, but should be put into practice. Human behavior is the core of socialism, the most direct external manifestation of values. Confucius said: "The body is, not to make the line; the body is not correct, although not from." Therefore, to help students establish the socialist core values is very important. Therefore, we must strengthen the campus behavior culture construction.

The Socialist Core Values Education Effectively Integrated into the Campus System Culture. Campus culture is to maintain a university order, so that the normal operation of a strong guarantee. It is like a ruler, regulate the behavior of teachers and students to correct the ideological understanding of college students on the errors. Campus system culture is to develop a practical campus system, and to implement, so that students develop good behavior habits. On this basis, to guide students to form the socialist core values.

Occupation of the Ideological and Cultural Network Construction of New Positions. With the rapid development of science and technology and the rapid development of mobile media technology, network and multimedia system has gradually become an important part of college students' study, work and daily life indispensable. Campus network culture covers all aspects of campus life. Campus network culture, through its unique affinity, plays an irreplaceable role in the formation of students' values.

\section{The Effective Integration of the Socialist Core Values Education into the Campus Construction Measures}

The Effective Integration of the Socialist Core Values Education into the Construction of the Campus Material Culture. 1. Integrate Education into Campus Architecture and Campus Design. Shaping celebrity statues, building educational windows and publicity columns, posting celebrity calligraphy and painting, the educational philosophy into the architectural design.

2. Large-scale Cultivation of School Beauty, School Grass. They carry the school tradition, school spirit, the campus of the ideal and the pursuit. They directly affect the senses of the students, as the spring rain to purify the human mind, play a cultural influence.

The Socialist Core Values of Education Effectively Integrated Into the Campus Spiritual and Cultural Construction Measures. 1. The formation of a unique campus culture. Campus culture often embodies the spirit of a university as a whole. In the formation of university have its own characteristics of university spirit, values, ideals, moral values, school concept, school motto, school spirit, style of study, teaching style.

2. Carry forward the spirit of school motto. Motto is not only the school spirit of the inheritance, it is shaping the criteria for consideration of outstanding students. The spirit of the school motto to infiltrate all aspects of running a school, so that the spirit of the school motto be inherited in the invisible, at the same time, but also a strong impetus to the formation of student socialism core values.

3. Give full play to the role of school history and archives. In the school history museum display a number of symbols of the school honor and motto of the items, through the campus of the campus of the spirit of culture. Through the history of the museum visit, exhibition, college students will deepen the understanding of the school's profound history and culture. Their pride and positive enthusiasm for the alma mater glory will come to fruition. So that "good learning, every day up" no longer stay for a simple slogan, but, correct attitude, down-to-earth, hard work, proactive, ever gives up. So that students in the future out of the gate when the country can become a pillar of talent for the motherland to contribute their part.

4. Held a series of high-level lectures and various cultural activities. Colleges and universities should take the socialist core values as the guide, so that students enjoy the charm of knowledge and wisdom, bathing science and human light. And constantly enrich the spiritual world of college students to enhance the spiritual realm of college students. 
The Effective Integration of Socialist Core Values Education into the Campus Behavior Culture Construction Measures. 1. To strengthen the construction of high-quality faculty. "Ten years of trees, a hundred years the tree," teachers not only to teach students knowledge, enhance the ability of students, but also to the noble moral integrity, the correct ideas as the core, through the actual behavior to precept, example for students, And promote students to practice the core values of socialism. At the same time, the establishment of "outstanding teachers", "excellent counselor" and other honorary titles. And the outstanding teachers on behalf of the deeds, through the propaganda bar, radio stations, school websites, television and other media for publicity, so as to establish a benchmark for the majority of teachers, teachers play an active role in infection and promote the formation of a good atmosphere.

2. Attach importance to ideological and political education. Ideological and political courses play an indispensable role in the formation of college students' values. The use of ideological and political courses, advocacy and promote the socialist core values. At the same time, in other courses can also penetrate the socialist core values education. To overcome the ideological and political theory courses outside the teaching of whatever discipline, regardless of educating people, "the CPC Central Committee and State Council on further strengthening and improving the ideological and political education of the views of" clearly require the majority of teachers "to explore various courses of ideological and political education Resources, in the process of imparting professional knowledge to strengthen ideological and political education, so that students in the process of learning scientific and cultural knowledge, consciously strengthen the ideological and moral cultivation, improve political awareness.

Should strengthen the traditional culture elective course strength. Especially for the relatively weak ideological and political foundation of science and engineering students should be through this way to enhance their ideological understanding. By teaching some examples of the lofty sentiments of historical literati, the core values of socialism and Chinese outstanding traditional culture stresses thoroughly, so that students can be inspired. Let the "patriotic, dedicated, honest, friendly" spirit, in the student body to be inherited, and effectively enhance the spiritual quality of students.

3. To enrich the second classroom activities of college students. Through the "theme of education, speech contest, knowledge contest, and academic report" and other colorful extracurricular activities, the students of the socialist core values of education. Improve the form of activities to attract the interest of students, so that students play in secondary schools, and effectively improve the participation of students in the activities. In the activity, let the teacher carry on the instruction; thus, enhances the student ability and the quality. "The paper come to the end feel shallow, never know the matter to practice" to enable students to consciously practice in the invisible core values of socialism, and thus the formation of good moral habits and behavior.

The Socialist Core Values of Education into the School System and Effective Cultural Construction Measures. 1. Encourage advanced, punish errors. Rewards and punishments clearly play a role in the psychological supervision from time to time.

2. Establish a "student-oriented" ideas. From the students are most concerned about, the most practical interests of the problem, the socialist core values of education and students to grow into practical difficulties and problems in the combination of the core values of education to enhance the socialist appeal and penetration.

Occupation of the Ideological and Cultural Network Construction of New Positions. 1. Increase the socialist core values of education channels. Open up to learn, promote and carry forward the socialist core values of the WeChat platform. At the beginning of the school, when the report to the class as a unit, focus on scanning two-dimensional code, so that each student to join the core values of socialism to promote the WeChat platform. In the promotion of content, to consider the audience of campus culture, not just publicity boring theory and framework. You can select a number of current affairs news, life tips, PubMed information, employment information and other useful information and set the connotation of humor as one of the small stories, for effective advocacy. And, combined with the socialist core values, scientific comment. The students will be 
virtually in the socialist core values related to the content of the mold. In this way, it can attract the interest of college students, improve the participation of college students, is conducive to the effective realization of the network ideological and cultural lead for the construction of campus culture to create a good network culture.

2. To strengthen the school-wide network monitoring and management. The establishment of a powerful network firewall, the reaction pages, illegal pages and pornographic web pages and other timely monitoring and timely clean-up, the objective of the socialist core values for college students to provide technical support.

3. Set up a network of civilized volunteer team. Through the network of civilized volunteer training, improve their network of civilized volunteer service ability and level. Network civilization volunteers to deeply agree with the socialist core values, and consciously on the network issued a "good voice of youth", the dissemination of China is the energy. In addition, the network against some of the socialist core values and violations of our Constitution, in violation of the four basic principles, is not conducive to national stability and is not conducive to national unity and other reactionary speech to resolutely resist, take the initiative to refute and actively report. Take the socialist core values as the guide; occupy the network ideological and cultural construction of the new position, objectively for the campus culture construction to purify the network environment. At the same time, to some extent, college students "do not disturb the noise, not for the rumor" to promote the formation of the socialist core values.

\section{Acknowledgements}

Project 1: 2015 Jilin Province Educational Science "12th Five-Year" general planning topic < Ordinary Higher Agricultural College Students Innovation Talent Training Mode Research > research results (No.: GH150216)

Project 2: One of the results of "agricultural university students study entrepreneurship education system", Jilin Provincial Department of education "12th Five-Year" social science research project (ID: Jilin Education Science topics[2015]NO.118)

\section{References}

[1] Cultivate and Practice the Socialist Core Values of Special Study January 2016 No. 1, total 258

[2] College ideological and political theory course selection of the Ministry of Education of Social Sciences Division

[3] College Students Socialist Core Value System Education Campus Culture Carrier Construction Research, Lv Dan

[4] with the Socialist Core Values to Lead the Construction of Campus Culture, Chen Guxin

[5] Liu Zheng, Research on College Students' identity and practice of socialist core values

[6] Hu Xinbao, Research on the construction of the socialist core values into the campus culture construction

[7] Song Yan, Research on the construction of the socialist core value system into the campus culture construction

[8] Hu Keying, Research on the education method of the socialist core values of College Students

[9] Han Guoshun, Research on the ideological and political education of College Students Guided by the socialist core value system

[10] Wang Lili, Research on the construction of the socialist core value system and the core values of College Students 